\title{
Relationship Between Length Variations of HTGR Fuel Rod Stack Lengths and Individual Rod Lengths
}
C. K. Bayne
D. R. Johnson

MASTER

\section{OAK RIDGE NATIONAL LABORATORY}




\section{DISCLAIMER}

This report was prepared as an account of work sponsored by an agency of the United States Government. Neither the United States Government nor any agency Thereof, nor any of their employees, makes any warranty, express or implied, or assumes any legal liability or responsibility for the accuracy, completeness, or usefulness of any information, apparatus, product, or process disclosed, or represents that its use would not infringe privately owned rights. Reference herein to any specific commercial product, process, or service by trade name, trademark, manufacturer, or otherwise does not necessarily constitute or imply its endorsement, recommendation, or favoring by the United States Government or any agency thereof. The views and opinions of authors expressed herein do not necessarily state or reflect those of the United States Government or any agency thereof. 


\section{DISCLAIMER}

Portions of this document may be illegible in electronic image products. Images are produced from the best available original document. 
Printed in the United States of America. Available from National Technical Information Service

U.S. Department of Commerce

5285 Port Royal Road, Springfield, Virginia 22161

Price: Printed Copy \$3.50; Microfiche $\$ 2.25$

This report was prepared as an account of work sponsored by the United States Government. Neither the United States nor the Energy Research and Development Administration/United States Nuclear Regulatory Commission, nor any of their employees, nor any of their contractors, subcontractors, or their employees, makes any warranty, express or implied, or assumes any legal liability or responsibility for the accuracy, completeness or usefulness of any information, apparatus, product or process disclosed, or represents that its use would not infringe privately owned rights. 
ORNL/TM-5544

Distribution

Category UC-77

Contract No. W-7405-eng-26

METALS AND CERAMICS DIVISION

THORIUM UTILIZATION PROGRAM (189a OH045)

Refabrication Development - Task 300

RELATIONSHIP BETWEEN LENGTH VARIATIONS OF HTGR FUEL ROD STACK LENGTHS AND INDIVIDUAL ROD LENGTHS

C. K. Bayne

Computer Science Division

D. R. Johnson

Metals and Ceramics Division

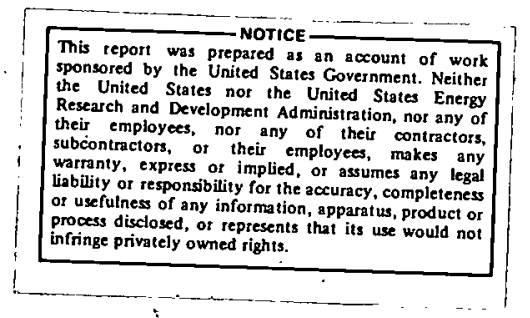

Date Published: October 1976

\footnotetext{
NOTICE This document contains information of a preliminary nature and was prepared primarily for internal use at the Oak Ridge National Laborutory. It is subjoct to revision or correction and therefore does not represent a final report.

OAK RIDGE NATIONAL LABORATORY

Oak Ridge, Tennesse.e 37830

operated by

UNION CARBIDE CORPORATION

for the

ENERGY RESEARCH AND DEVELOPMENT ADMINISTRATION
} 
THIS PAGE

WAS INTENTIONALLY

LEFT BLANK 


\section{CONTENTS}

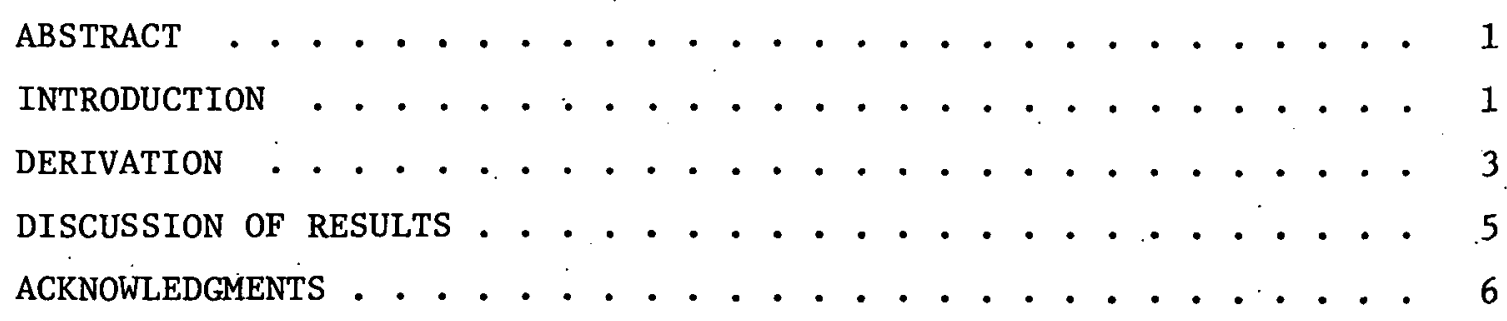


RELATIONSHIP BETWEEN LENGTH VARIATIONS OF HTGR FUEL ROD STACK LENGTHS AND INDIVIDUAL ROD LENGTHS

C. K. Bayne* and D. R. Johnson

ABSTRACT

\begin{abstract}
A mathematical relationship between the length variation of individual HTGR fuel rods and the length tolerance of a stack of fuel rods has been derived. The variations in fuel rod lengths were assumed to be distributed normaliy with known mean and standard deviation. If individual fuel rod lengths are within a length $\mathrm{L} \pm \theta,(1-\alpha) \%$ of the time and a stack of 15 rods is within $15 \mathrm{~L} \pm \delta,(1-\alpha) \%$ of the time then $\theta=(0.258) \delta$ for all values of $\alpha$. The specification for $\delta$ will likely be $0.25 \mathrm{in.;}$ which corresponds to $\theta=0.060 \mathrm{in}$. However, we can manufacutre rods by the slug injection process with an actual $\theta$ of 0.018 in. Thus, out-of-specification rod stacks will be extremely rare; so development of special equipment to recycle the out-of-specification stacks will not be necessary.
\end{abstract}

\title{
INTRODUCTION
}

The fuel for the High-Temperature Gas-Cooled Reactor consists of coated fuel particles that are bonded together with pitch and graphite powder to form molded cylindrical fuel rods. 'The fuel rods are stacked into blind holes in a prismatic graphite fuel block (Fig. 1).

As the graphite block shrinks relative to the fuel column during irradiation, it is important that an adequate axial void be provided between the fuel column and the graphite block. Otherwise, the diferential contraction might result in mechanical damage to the fuel. The size of the space between fuel column and graphite block depends upon whether the void is at one end of the column or distributed among the fuel rods. The tolerance on the total void in a fuel column is expected to be $\sim \pm 0.25$ in.

In the manufacturing of HTGR fuel rods, this void requirement can be expressed as the tolerance on the length of a stack of 15 individual

\footnotetext{
${ }^{*}$ Computer Science Division
} 


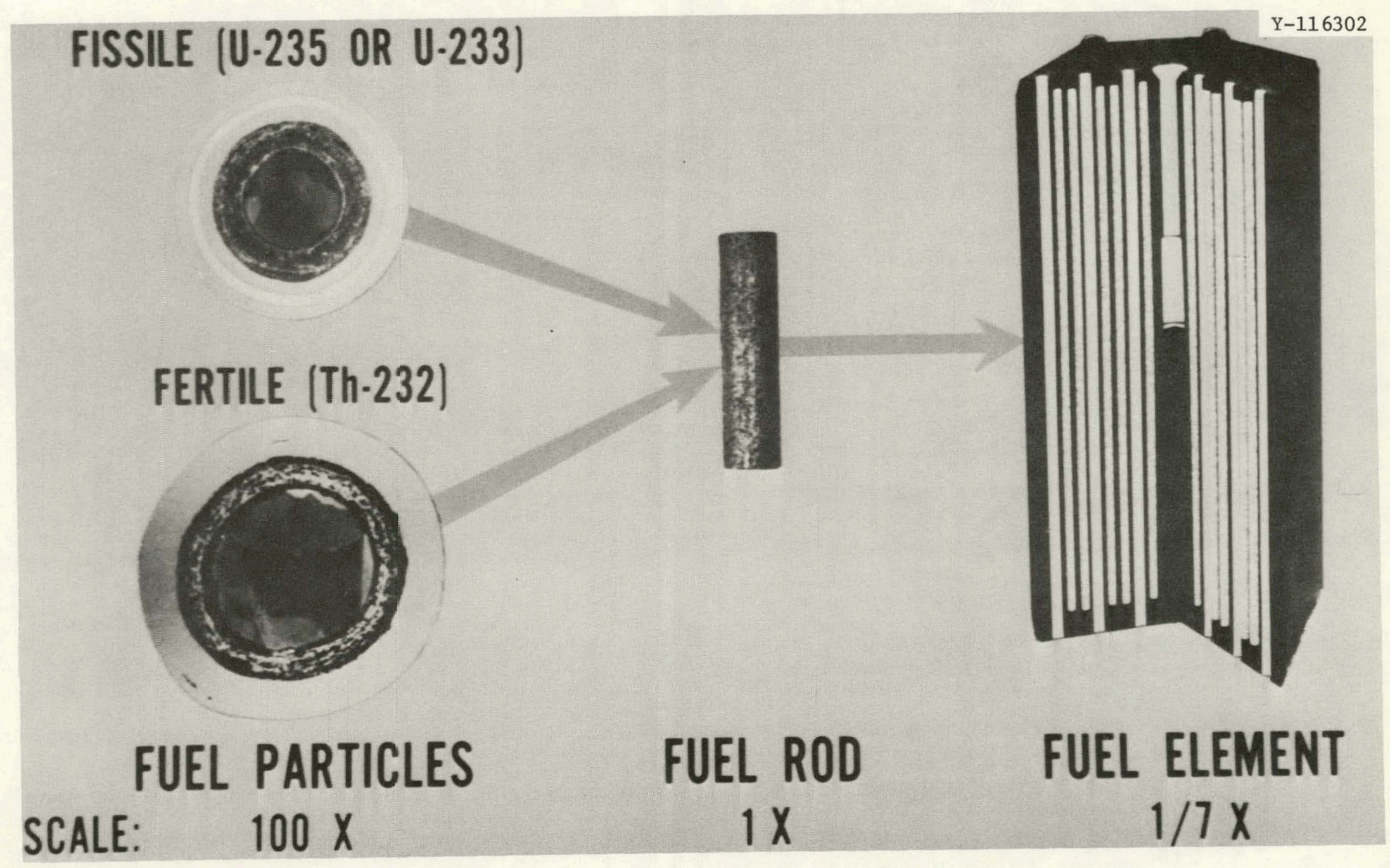

Fig. 1. HTGR Fuel Components. 
fuel rods, nominally 2 in. long; the distribution of the variation in the fuel rod lengths is approximately normal (Fig.2). Figure'2 shows a normal probability plot for fuel rods manufactured to a fuel rod length of 1.99 in., the mean fuel rod length can be changed at will by adjusting the fuel rod molding equipment. The present work is a method to calculate the required dimensional specifications for individual fuel rods when the tolerance for the stack of 15 fuel rods is known.

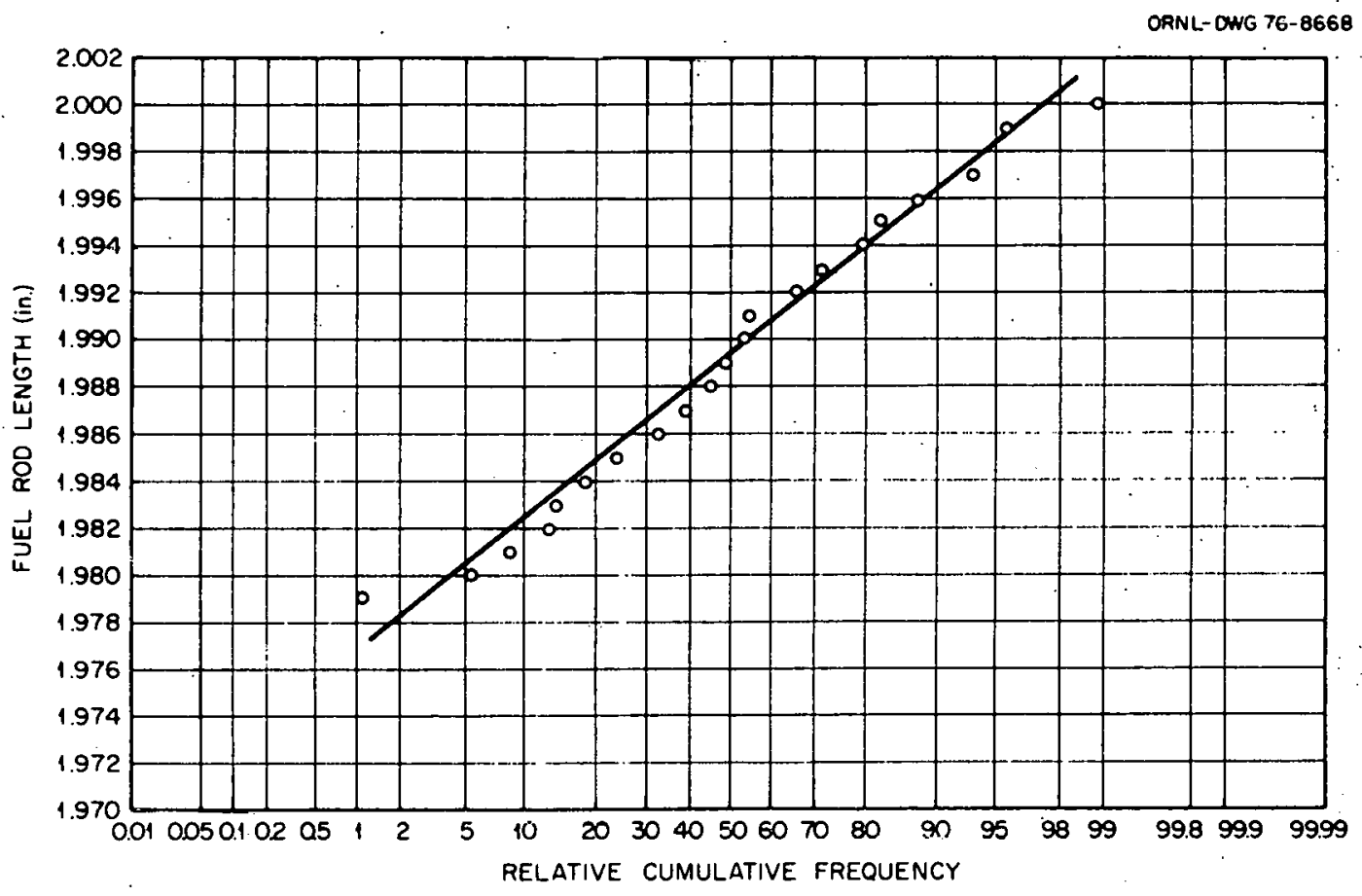

Fig. 2. Probability Plot of Lengths of Slug Injectèd Fuel Ruds.

\section{DERIVATION}

A number of definitions must be established:

Let $\ell_{i}, i=1,2, \ldots, n$; be the observed lengths of $n$ individual fuel rods.

Let the expected value of each individual rod length be $L$.

Let the standard deviation of the individual lengths be $\sigma$.

Let $T L$ be the total length of $n$ fuel rods, $T L=\sum_{i=1}^{n} l_{i}$. 
The expected value of $T L$ will be $n L$ and the standard deviation of $T L$ will be $\sqrt{n} \sigma$.

Then given the requirement that with $(1-\alpha)$ probability, $T L$ is within the interval $n L \pm \delta$,

$$
\operatorname{Pr}(n L-\delta<T L<n L+\delta)=1-\alpha,
$$

we wish to derive an expression for $\theta$ as a function of $\delta$ such that

$$
\operatorname{Pr}\left(L-\theta<\ell_{i}<L+\theta\right)=1-\gamma
$$

The fuel rod lengths which are assumed to be independently normally distributed can be transformed by $z_{i}=\left(l_{i}-L\right) / \sigma$ to independently normally distributed random variables with mean 0 and standard derivation 1. Tables of the percentage points of the normal random variable $Z$ : [i.e., the number $Z_{\beta}$ such that $\operatorname{Pr}\left(Z>Z_{\beta}\right)=\beta$ ] can be found in most statistical handbooks.

In the inequality (2) one can subtract $L$ and divide by $\sigma$ to obtain

$$
\operatorname{Pr}\left[-\theta / \sigma<\left(\ell_{i}-I_{1}\right) / \sigma<\theta / \sigma\right]=1-\gamma,
$$

Then

$$
\theta / \sigma=z /{ }_{2}
$$

and

$$
\sigma=\theta / 2_{\gamma / 2}
$$

By transforming the normally distributed variable $T L$ from Eq. (1), we can follow a similar argument to derive an expression relating $\sigma$ and $\delta$ :

$$
\operatorname{Pr}[-\delta / \sqrt{n} \sigma<(T L-n L) / \sqrt{n} \sigma<\delta / \sqrt{n} \sigma]=1-\alpha,
$$


Then

$$
\delta / \sqrt{n} \sigma=Z_{\alpha / 2},
$$

and

$$
\sigma=\delta \sqrt{n} z_{\alpha / 2}
$$

From (5) and (8) it is apparent that

$$
\theta / Z_{\gamma / 2}=\delta / \sqrt{n} z_{\alpha / 2}
$$

$o x$

$$
\theta=\delta z_{\gamma / 2} / \sqrt{n} z_{\alpha / 2}
$$

Equation (10) is our desired result.

\section{DISCUSSION OF RESULTS}

Suppose we are going to make $n=15$ fuel rods with each fuel rod $2 \pm \theta$ in. in length. On the average only $\gamma \%(\gamma=5 \%, 1 \%, 0.1 \%)$ of the fuel rods will be rejected if they have lengths greater than $2+\theta$ in. or less than $2-\theta$ in. We would like to find the values of $\theta$ such that $\operatorname{Pr}\left(30-\delta<\sum_{i=1}^{n} \ell_{i}<30+\delta\right)=1-\alpha$, when $\alpha=0.05,0.01$, and 0.001 .

The percentile values 1.96 (for $\alpha=0.05$ ), 2.58 (for $\alpha=0.01$ ), and 3.29 (for $\alpha=0.001$ ) may be used with (Eq. 10) with different values of $\gamma$.

. The $\theta$ values are listed in Table 1 for any value of $\delta$. We should note that if $\alpha-\gamma$ then the value of $\theta$ is $\theta=\delta / \sqrt{15}=0.258 \delta$, which is independent of the value of $\alpha$ or $\gamma$. Under the normality assumption, if there is a high degree of confidence that the lengths of the fuel rod will be within the tolerance range of $2 \pm 0.258 \delta$ then there should be the same high degree of confidence that the total length will be within 
the tolerance range $30 \pm \delta$. For example, if $\delta=0.25 \mathrm{in}$. and $\gamma=0.001$ and $\alpha=0.001$ then the value of $\theta$ is $\theta=0.258(0.25 \mathrm{in}$.) $=0.060 \mathrm{in}$. That is, if $99.9 \%$ of the fuel rods are manufactured within $2.000 \pm$ 0.060 in., then the stack will be within $30.00 \pm 0.25 \mathrm{in} .99 .9 \%$ of the time. Recent data for 92 fuel rods manufactured by the slug injection process yielded a standard deviation of $0.0056 \mathrm{in}$. Thus, the 30 limit for the individual rod lengths is $\pm 0.018 \mathrm{in}$., much better than the $\pm 0.060 \mathrm{in}$. required for the void requirements. These considerations led to the conclusion that out-of-specification stacks of fuel rods will be extremely rare. This conclusion is important to the HTGR Fuel Refabrication Development Program as it indicates that the development of equipment for handling out-of-specification stacks will not be required. In the remote refabrication of $H T G R$ fuel, the most efficient handing of the occasional out-of-specification fuel rod stacks may be to scrap them rather than develop systems to recombine the: rods with other rods to form acceptable stacks.

Table 1. Values of $\theta$ for Various Values of $\alpha$ and $\gamma$

\begin{tabular}{cccc}
\hline & \multicolumn{3}{c}{$\theta$ for each $\alpha$ value } \\
\cline { 2 - 4 } & 0.05 & 0.01 & 0.001 \\
\hline 0.05 & $0.258 \delta$ & $0.196 \delta$ & $0.154 \delta$ \\
0.01 & $0.340 \delta$ & $0.258 \delta$ & $0.203 \delta$ \\
0.001. & $0.433 \delta$ & $0.329 \delta$ & $0.258 \delta$ \\
\hline
\end{tabular}

\section{ACKNOWLEDGMENTS}

Technical discussions with R. A. Bradley and W. R. Hamel are gratefully acknowledged. The manuscript was edited by George W. Griffith and typed by Denise Campbell of the Metals and Ceramics Division Reports office. 
ORNL/TM-5544

Distribution

Category UC-77.

INTERNAL DISTRIBUTION

1-2. Central Research Library

3. Document Reference Section

4-8. Laboratory Records Department

9. Laboratory Records, ORNL RC

10. ORNL Patent office

11. P. Angelini

12-16. C. K. Bayne

17. J. J. Beauchamp

18. K. O. Bowman

19. R. A. Bradley

20. A. J. Caputo

21. J. A. Carpenter

22. W. L. Carter

23. S. J. Chang

24. H. E. Cochran

25. J. H. Coobs

26. W. H. Cook

27. D. A. Costanzo

28. R. R. Coveyou

29. F. C. Davis

30. J. P. Drago

31. R. G. Donnelly

32. B. C. Duggins

33. W. P. Eatherly

34. J. I. Federer

35. D. A. Gardiner

36. D. G. Gosslee

37. L, J. Gray

38. P. A. Haas

39. C. C. Haws

40. W. R. Hamel

41. F. E: Harrington

42. T. L. Hebble

43-45. M. R. Hill

46. F. T. Homan.
47-51. D. R. Johnson

52. V. E. Kane

53. M. J. Kania

54-56. P. R. Kasten

57-60. R. K. Kibbe

61 . R. W. Knoll

62. W. J. Lackey

63. E. Leach

64. W. E. Lever

65. T. B. Lind emer

66. E. L. Long, Jr.

67-68. A. L. Lotts

69. J. E. Mack

70. S. R. McNeany

71. F. L. Miller, Jr.

72. T. J. Mitchell

73. K. J. Notz

74. A. R. O1sen

75. W. H. Pechin

76. J. E. Rushton

77. T. F. Scanlan

78. J. H. Shaffer.

79. J. W. Snider

80. D. P. Stinton

81. R. R. Suchomel

82. V. J. Tennery

83. T. N. Teigs

84. D. B. Trauger

85. V.R.R. Uppuluri

86. J. E. Van Cleve

87. R. C. Ward

88. J. R. Weir

89. G. W. Weber

90. D. G. Wilson 
EXTERNAL DISTRIBUTION

91-98. ERDA DIVISION OF NUCLEAR FUEL CYCLE AND PRODUCTION, Washington, DC 20545

Director (2)

R. G. Bradley (1)

W. S. Schieb (5)

99-100. ERDA DIVISION OF REACTOR NUCLEAR RESEARCH AND APPLICATIONS, Washington, DC 20545

Director

101-102. ERDA IDAHO OPERATIONS OFFICE, P.0. BOX 2108, Idaho Falls, ID 83401

C. E. Williams, Manager

Barry Smith

103. ERDA OFFICE OF PROGRAM MANAGEMENT, RESEARCH AND SPACE PROGRAMS, P.0. Box 81325, San Diego, CA 92138

J. B. Radcliffe

104. ERDA SAN FRANCISCO OPERATIONS OFFICE, 1333 Broadway, Wells Fargo Bldg., Oakland, CA 94612

R. D. Thorme, Manager

105-107. ERDA OAK RIDGE OPERATIONS OFFICE, P.O. BOX E, Oak Ridge, TN 37830

Director, Research and Technical Support Division

Direstor, Reactor Division

F. E. Dearing, Reactor Division

108-278. ERDA TECHNICAL INFORMATION CENTER, P.O. Box 62, Oak Ridge,'TN 37830

For distribution as shown in TID 4500 Distribution Category UC-77゙-Gas-Conled Reactor Technology 